\title{
ニオブおよびタンタルの製造*
}

\section{Production of Tantalum and Niobium Metalpowders}

\section{1.ま えがを}

ニオブとタンタル金属の粉末を充ようとする試みは， 不純な製品しか造れなかったが，かなり古くから行なわ れてきた.すでに，1864年，Blomstrand は，五塩化物 を赤熱したガラス管中で水素還元し，金属二オブらしい 粉末をえたと報告している。さらに，1906 年，Werner は，アルミニウム・テルミット法で粗ニオブ金属をつく り，これを真空炬中で加熱蒸留をくり返してかなり高純 度の金属粉を製造したと述べ，ついで 1929 年, Balke は初めて板祸よび棒状の金属ニオブまで加工した。

現在までに提案されたニオブとタンタル金属の製造法 は，大別するとつぎのようになる ${ }^{16)}$.

（1）フッ化物複塩などの融解塩電解

(2) 酸化物の炭化物侸よる還元

（3）フッ化物，壏化物などのナトりウム還元22233

(4) 五塩化物のマグネシウムをたはカルシウム還 元 $^{4) 51}$

（5）三塩化物の水素またはマグネシウム還元677

（6）酸化物のマグネシウムをたはカルシウム還元 ${ }^{3)}$

筆者らは，塩素化法によって製錬を行なってきた関係 から，(4) と（5）の方法在主にし，(6) の方法とも比加 くしながら実験した，そして塩化物を還元する各種の方 法の優少を，できるだけ工業的見地に立って判定しょう とする目的で研究した注1).

な拓記述の便宜上，䢬元操作を三大別して委とめた。

\section{2. ッエペリン法}

三壏化物，酸化物などは高沸点で簡単には気化しない から，特別な還元法が必要となる．普通は，初めから還 元剂を配合しバッチ式で行なう。つまり，密閉炣（また はオートクレーブ）中で加熱点火し，瞬間的に還元して しまうッェペリン法である゙。.この方法では，反心が急 激なので, 散乱する量が多く，特に五塩化物のように低 沸点の化合物に対しては收率の低下がはなばしい。

筆者らは、ツェペリン法でえられる金属の純度と収率 を、今まで報告のない各種のニオブとタンタル化合物に

*ニオブおよ゙タンタルの製鍊（第 5 報） Metallurgy of Niobium and Tantalum (Part 5)

** 工技院 電気試験所（東京都千代田区永田町 2 )

\section{石山豊 次**, 黒 田 正** \\ Toyoji IshiYama, Tadashi Kuroda}

ついて広く実験し，工業的に成立するかどうかを検討す る方針をたてた。

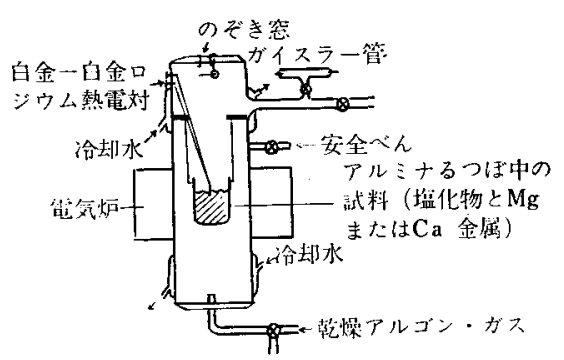

図 1 ソェペリン法還元师格図

（1）実験装置およひ操作実験装置を図1亿示 す.実験操作は，塩化物（または酸化物）をマグネシウム かカルシウム金属とよく配合し，この試料をアルミナる

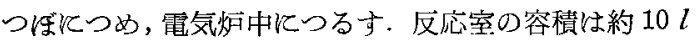
である.この試料をシリコニット抵抗体で, 真空ポンプ で減圧しながら（約 $10^{-3} \mathrm{mmHg}$ まで）外部から加熱す る・カルシウムを使用するときには，点火しやすいよう に少量のマグネシウム・リボンを加壳た．還元用マグネ シウム金属恃，五かじめ希硝酸，水，アセトンの順に 洗浄し, 真空乾燥を行い ${ }^{10)}$ カルシウム金属は旋盤で切削 後、直ちにその新しい小片を使用した.

酸化物の還元反応は激烈なので, 初め還元炉を開放し たままマグネシウム・リボンにより点火し，反応終了後 直ちに密閚，真空ポンプで咸王してアルゴン・ガスを送 りこむ，図 1 の装置を用いて $50 \mathrm{~g}$ の酸化物を還元する とき，火炎は約 2 メートルの高さ采で吹き上げ，マグネ シア粉などが散乱した．三塩化物を $50 〜 200 \mathrm{~g}$ 還元する

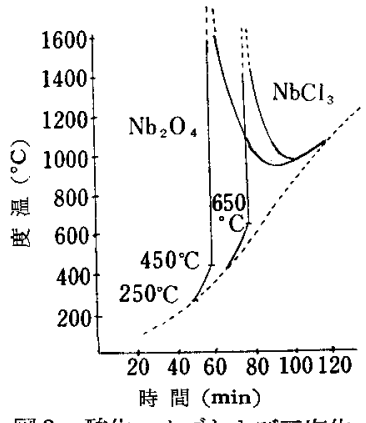

図 2 酸化二オブおよび三塩化二 オブのマグネシウム遠元 とき，点火すると，るつ ぼ内の温度は $1600^{\circ} \mathrm{C}$ 以 上飞達し，外部加熱を中 此後死約 $30 \mathrm{~min} \sim 1.5 \mathrm{~h}$ 近くその温度定保った。 Temple 乞同様にして測 定した結果を図 2 に示す 21)、いずれのとき飞り，点 火後，排気が完了すれば 直ちにアルゴン・ガスを 送り注2,9冷却しはじ。， 
表 1 ッェッペリン法によるニオブおよびタンタル金属の製造

\begin{tabular}{|c|c|c|c|c|c|c|c|c|c|c|c|c|c|c|c|c|c|}
\hline 試 & 料 & 還 & 元 & 諭 & 金 & 属 粉 & & & & 驰 度 & $お$ & $ひ$ & 不 純 & 物 & (\%) & & \\
\hline 種 & 量 (g) & 種 類 & 量 (g) & 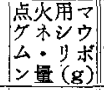 & 収量 (g) & 收率 (\%) & $\mathrm{Nb}$ & Ta & $\mathrm{Ca}$ & $\mathrm{Si}$ & $\mathbf{M g}$ & Al & C & $\mathrm{Fe}$ & そ & $\infty$ & 他 \\
\hline $\mathrm{NbCl}_{5}$ & 50 & $\mathrm{Mg}$ & 16 & & 10.3 & 60 & 97.6 & 1.5 & & 0.3 & 0.1 & 0.1 & 0.2 & 0.2 & $\mathbf{w}, \mathbf{T} \mathbf{i}, \mathrm{s}$ & $\mathrm{Sn}, \mathrm{Mn} \mathrm{tr}$ & race \\
\hline$"$ & 100 & $"$ & 34 & & 22.4 & 65 & $"$ & $"$ & & $"$ & $"$ & $"$ & $"$ & $"$ & & $"$ & \\
\hline$"$ & 200 & 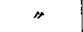 & 60 & & 37.8 & 62 & $"$ & $"$ & & 0.2 & 0.2 & " & 0.3 & 0.1 & & $"$ & \\
\hline $\mathrm{TaCl}_{5}$ & 50 & $"$ & 20 & & 14.5 & 58 & 2.0 & 96.2 & & $"$ & 0.1 & " & 0.2 & 0.2 & & $"$ & \\
\hline " & 100 & " & 35 & & 30.5 & 60 & $"$ & $"$ & & $"$ & $n$ & $"$ & $"$ & $"$ & & $"$ & \\
\hline * & 200 & $"$ & 55 & & 63.5 & 63 & " & 96.3 & & 0.1 & 0.2 & * & $\Rightarrow$ & 0.1 & & $"$ & \\
\hline $\mathrm{NbCl}_{5}$ & 50 & $\mathrm{Ca}$ & 25 & 0.5 & 11.2 & 65 & 97.6 & 1.5 & 0.2 & 0.3 & & * & 0.1 & 0.2 & & $"$ & \\
\hline " & 100 & $"$ & 45 & $"$ & 22.5 & $"$ & $"$ & $"$ & 0.3 & $\Rightarrow$ & & $"$ & 0.2 & 0.3 & & $"$ & \\
\hline$"$ & 200 & $"$ & 85 & " & 46.8 & 68 & 97.5 & $"$ & $"$ & 0.2 & & $"$ & $"$ & 0.2 & & $"$ & \\
\hline $\mathrm{TaCl}_{5}$ & 50 & $"$ & 20 & " & 15.2 & 60 & 2.0 & 97.2 & 0.2 & $"$ & & " & 0.1 & $"$ & & $"$ & \\
\hline$"$ & 100 & $"$ & 40 & $"$ & 31.8 & 63 & $"$ & 97.0 & 0.3 & $"$ & & $"$ & 0.2 & " & & $"$ & \\
\hline$n$ & 200 & $"$ & 75 & " & 65.5 & 65 & $\Rightarrow$ & 97.1 & 0.2 & 0.1 & & $"$ & 0.3 & $"$ & & $"$ & \\
\hline $\mathrm{NbCl}_{3}$ & 50 & $\mathbf{M g}$ & 15 & & 16.2 & 70 & 97.7 & 1.5 & & 0.3 & 0.1 & $"$ & 0.1 & 0.2 & & $"$ & \\
\hline " & 100 & $"$ & 30 & & 32.5 & $"$ & 97.8 & * & & 0.2 & $"$ & $"$ & 0.2 & 0.1 & & $"$ & \\
\hline $\mathrm{TaCl}_{3}$ & 50 & $"$ & 10 & & 21.5 & 68 & 2.2 & 97.1 & & " & $*$ & * & 0.1 & 0.2 & & $"$ & \\
\hline$\Rightarrow$ & 100 & $"$ & 20 & & 44.0 & 70 & " & 97.0 & & $"$ & " & $"$ & 0.2 & $"$ & & $"$ & \\
\hline $\mathrm{NbCl}_{3}$ & 50 & $\mathrm{Ca}$ & 25 & 0.5 & 16.0 & $"$ & 97.7 & 1.3 & 0.2 & 0.3 & & $"$ & $"$ & $"$ & & " & \\
\hline " & 100 & $"$ & 45 & $"$ & 33.0 & 72 & $"$ & " & 0.3 & 0.2 & & $"$ & 0.3 & 0.1 & & " & \\
\hline $\mathrm{TaCl}_{3}$ & 50 & $"$ & 15 & $\Rightarrow$ & 22.0 & 71 & 2.2 & 96.9 & 0.2 & 0.3 & & $"$ & 0.1 & 0.2 & & $\Rightarrow$ & \\
\hline$"$ & 100 & $"$ & 30 & $"$ & 44.5 & 72 & $\Rightarrow$ & $"$ & 0.3 & 0.1 & & $"$ & 0.3 & 0.1 & & $\Rightarrow$ & \\
\hline $\mathrm{Nb}_{2} \mathrm{O}_{5}$ & 50 & $\mathbf{M g}$ & 35 & & 18.0 & 50 & 92.6 & 2.5 & & 0.2 & 0.1 & $"$ & 0.4 & $"$ & $"$ & $\mathrm{Nb}_{2} \mathrm{O}_{5}$ & 4.0 \\
\hline $\mathrm{Ta}_{2} \mathrm{O}_{5}$ & $"$ & $"$ & 25 & & 22.5 & 55 & 3.0 & 93.3 & & 0.1 & $"$ & $"$ & 0.3 & " & $"$ & $\mathrm{Ta}_{2} \mathrm{O}_{5}$ & 3.0 \\
\hline $\mathrm{Nb}_{2} \mathrm{O}_{5}$ & " & $\mathrm{Ca}$ & 50 & 1.0 & 21.0 & 60 & 91.5 & 2.5 & 0.2 & 0.2 & & $"$ & 0.2 & 0.2 & $"$ & $\mathrm{Nb}_{2} \mathrm{O}_{5}$ & 5.0 \\
\hline $\mathrm{Ta}_{2} \mathrm{O}_{5}$ & " & $"$ & 35 & $"$ & 19.5 & 63 & 3.0 & 90.6 & 0.1 & $"$ & & " & 0.3 & 0.1 & " & $\mathrm{Ta}_{2} \mathrm{O}_{5}$ & 5.5 \\
\hline $\mathrm{Ta}_{2} \mathrm{O}_{5}, \mathrm{CaCl}_{2}$ & 50,50 & . & 40 & " & 26.0 & 65 & $"$ & 92.1 & 0.2 & 0.1 & & $"$ & $"$ & $"$ & $"$ & " & 4.0 \\
\hline $\mathrm{TaOCl}_{3}$ & 50 & $\mathbf{M g}$ & 30 & & 14.5 & 50 & 2.0 & 82.6 & & 0.2 & 0.2 & $"$ & " & s & 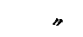 & $\mathrm{TaOCl}_{3} 1$ & $15.0^{*}$ \\
\hline $\mathrm{K}_{2} \mathrm{NbF}_{7}$ & $"$ & $\Rightarrow$ & 20 & & 6.5 & $"$ & 93.0 & 1.5 & & 0.5 & $?$ & 0.5 & 0.4 & $\Rightarrow$ & $\Delta$ & $\mathbf{M g F}_{\mathbf{2}}$ & 4.0 \\
\hline $\mathrm{K}_{2} \mathrm{TaF}_{7}$ & $"$ & $"$ & 15 & & 12.0 & 45 & 2.0 & 94.6 & & $"$ & $?$ & " & 0.5 & $\Rightarrow$ & $"$ & $"$ & 2.5 \\
\hline
\end{tabular}

* $\mathrm{TaOCl}_{3}$ または $\mathrm{Ta}_{2} \mathrm{O}_{5}$

内部まで常温澾してから陚料をとり出した，還元哣の 器壁には,塩化マグネシウム,塩化カルシウム, 、グネシ ア，生石灰などが附着している，純アルミナるつぼは， 直径 $8 \mathrm{~cm}$, 高さ $7 \mathrm{~cm}$ で，温度の急上显でき裂が入るこ とはあったが，内容物はもれ出さなかった。

るつぼからとり出した黒色の軽石状武料は，まず大量 の水で洗浄し, $10 \%$ の塭酸で煮沸し,さらに水, アルコ 一ル，エーテルの順に洗い， $200^{\circ} \mathrm{C} て ゙$ 真空乾燥した．こ ろして，微細なニオブとタルタンの金属粉末を党た。

（2）実験結果と考察 実験結果表 1 亿示す，収 率と純度は, ともに後述の二方法とくらべて良好ではな い. 収率の悪い理由としては, 反応が激しいため, 未反 応の塩化物（または酸化物など）はるちろん，還元され

注 1 フッ化物複塩のナトリウム邆元は古くから行われており，報文し多 いので，参考実験として追試寸る程度にとどめた。塩化物のナトリ

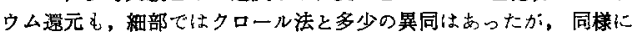
すぐれた結果をおさめた，三塩化物の融解塩電解法は，dispropor

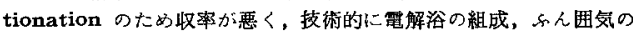
保持などいるいるの困難かおたり，好辕果はえられなかった。

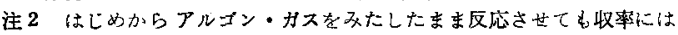
はとんど影響しない。のウランのばあいを参照.
た金属粉末まで散乱し，炉壁などに附着してしまうため が主で，洗浄のときの流失などるいくらか影響すると考 党れる。

五塩化物は，低沸点のため反応せずと気化し散乱する 量が多く好結果はえられない。酸化物は, 反忘が爆発に 近く，一瞬間で終了するため，危険もあり，叹率も悪 い'11.フッ化物複塩のマグネシウム還元では，生成した フッ化マグネシウムが濃硝酸にわずかに溶けるだけで， 沸点も高く除去しにくいので還元金属粉中残存する. 三塩化物については，収率はやや良く，マグネシウム，

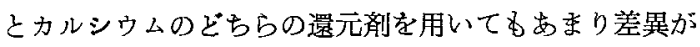
なく, しかも高純度の品筫が签易に兄られ, 安価でとり 投いやすいなどの理由るあり ${ }^{10)}$ ，マグネシウムが有利と 思われる．また，マグネシウム還元によった方が，還元 後, 塩化マグネシウムを酸処理によらず，真空蒸留で除 去することる低沸点なので容易に行える ${ }^{10)}$.

このツェペリン法は, 再現性にとぼしいから には収率と綍度の平均值を示した。不純物として、、グ

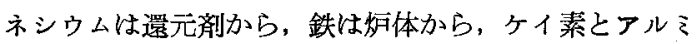


ニウムはるつぼなどから混入すると考えられ，大規模に 行な竞ば，かなり混入を防げると推定される．炭素は炉 体, 三塩化物, 還元用マグネシウムなどに附着する有機 物その他から混入すると考完られる。

ツェペリン法で製造した金属粉の粒度は，90\% 以上 が 250 メッシュより微細である.ニオブとタンタル金属 粉についての差異は出り明らかではないが，ニオブの 方がやや粗で，還元剤で区別するとマグネシウムの方が 粗, 原料別では三塩化物, 五塩化物, フッ化物複塩, 酸 化物の順に粗から細となる。還元のとき，酸化卜リウム のようK，モリブデン製ボンベで行えば純度は向上し ${ }^{13}$ ， 塩の高温での流動性をますため塩化カルシウムを添加

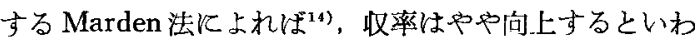
れている。

以上の上うに，表1から，筆者らは，ツェペリン法の うち, 純度, 收率などの点で，大規模の工業生产の可能 性を考えることができるのは，三塭化物のマグネシウム 還元だけと判断した。

\section{3. クロール法}

クロール法は，すでにチタニウム、ジルコニウムなど の大量生産に応用され，タンタルについても，Johansen ら 礼よって武及られている．筆者らは，この方法を二 オブにる応用し，比かく検討を行なった。

（1）実験装置およひ操作 実験装置の構成は，水 素のかわりKアルゴンを用い，還元部分にマグネシウム をみたしたボートを置く潘かは，大体三塩化ニオブの製 造のときと同じである ${ }^{15)}$.

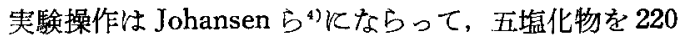
$\sim 250^{\circ} \mathrm{C}$ 飞電気炉で加熱気化させ, 乾燥したアルゴン・ ガスにのせて運ぶ。このとき，アルゴン・ガスの流速と 五塩化物の気化温度を適当化調節して, 未反応の五㙁化 物をできるだけ减少させるようにする。る ま来応五塩 化物が排気側に析出した場合は，アルゴン・ガスの導入 方向を逆に切りか党てその部分を加熱し，再びマグネシ ウムと反応させる，反応管は石英で，中央部を電気炬に より約 $750^{\circ} \mathrm{C}$ に加熱し，白金ボート内にみたしたマグネ シウムを融解して拓く（大量汇還元するときは，ボート の材質はモリブデンまたは黒鉛でるよい)。アルゴン・ガ
スにのって運ばれてきた五塩化物は，ボ一ト内の融解、 グネシウムと反応し，還元されて，ニオブまたはタンタ ルの金属粉となり，ボ一ト内残る，末反応の五塩化物 は，そのままアルゴン・ガスに運ばれて通過し，冷却部 に析出する.

五塩化物が気化しつくし，反忘が終了したらば，アル ゴン・ガスをみたしたま秀冷却し，粗海綿状金属粉をと り出す. これを真空炬に入れ, $900^{\circ} \mathrm{C}$ 前後で減圧蒸留し， 程化マグネシウムと過剩のマグネシウム金属とを除去す る. 冷却後、アルゴン・ガスをるたしたままとり出し， 粉砕し，エーテルで洗い乾爆すれば微細なニオブまたは タンタル金属粉末をえる。

（2）実験結果亡考察 実験結果を表 2 亿示す，収 率が低下寸る理由としては未反応の五塩化物が捕捉でき ず散乱すること，還元後の処理による損失が主である。 不純物として，アルミニウム，ケイ素は反応管から，炭 素はボートなどから，マグネシウムは還元剤から，鉄は 五塩化物中の不純物から混入すると考学られる．大規模 になる注ど器壁などからの混入率が少なくなるから，高 純度となり，反応率も向上すると推定される，還元後の 金属粉末の粒度は、ツェペリン法のときと同じく，90\% 以上が 250 メッシュより微紐である。

還元速度は，初めはかなり急速であるが，五㫫化物を 送り続けるにつれて，次第に招そくなり，反応しがたく なる．この理由として，瀜解マグネシウム粒子のまわり を還元生成した二オブまたはタンタル金属粉末が包み， 括括いか々し，次第にマグネシウムと五㙁化物との接触 をさまたげる結果と考觉る， $750^{\circ} \mathrm{C}$ で生成した塩化、 グネシウムも融解して

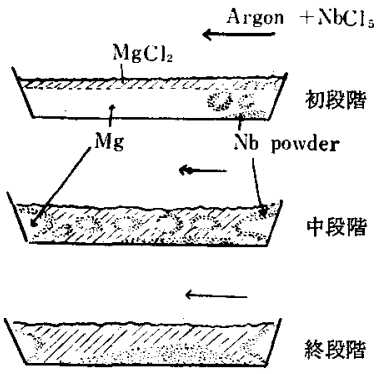

図3クロール法の還元機楧 いるから，反応途中の ボートを急命後とり出 乙観察し，反応進行状 洗を推定し，図示する と、挧3のようにな る、冷却部に析出する 五塩化物量加巨還元反 応速度が抢そくなった と判定したなら，短時 間だけ， $750^{\circ} \mathrm{C}$ から温

表 2 クロール法によるニオブおよびタンタル金属の製造

\begin{tabular}{|c|c|c|c|c|c|c|c|c|c|c|c|c|c|c|}
\hline 塩 & 化 & 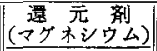 & 金 属 & 末 & \multicolumn{3}{|c|}{ 純 } & 度 & $\therefore$ & 不 純 & 物 ( & & & \\
\hline 種 類 & 量 (g) & 量（g） & 収量 (g) & 収率 $(\%)$ & $\mathrm{Nb}$ & $\mathbf{T a}$ & Si & $\mathbf{M g}$ & Al & C & $\mathrm{Fe}$ & $z$ & の & 他 \\
\hline $\mathrm{NbCl}_{5}$ & 10 & 3.5 & 2.6 & 75.0 & 98.1 & 1.4 & 0.1 & 0.1 & 0.1 & 0.1 & 0.1 & $\mathbf{W}, \mathbf{T}$ & $\mathbf{S n}, \mathbf{M n}$ & trace \\
\hline " & 20 & 6.5 & 5.3 & " & " & $"$ & $"$ & " & s & " & $"$ & & $"$ & \\
\hline $\mathrm{TaCl}_{5}$ & 10 & 3.5 & 3.6 & 72.0 & 1.8 & 97.8 & $"$ & 0.05 & 0.05 & $\Rightarrow$ & " & & " & \\
\hline$"$ & 20 & 7.0 & 7.8 & 75.0 & $"$ & " & $\Rightarrow$ & " & $"$ & 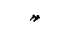 & $\Rightarrow$ & & $\Rightarrow$ & \\
\hline " & 138.7 & 33.54 & 61.0 & 77.5 & 0.1 & 99.8 & $"$ & 0.001 & 0.01 & 0.016 & $?$ & & $?$ & \\
\hline
\end{tabular}

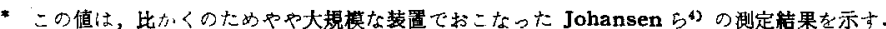


度を約 $10 \sim 20^{\circ} \mathrm{C}$ 前後急激に上昇させ, 刺げきしてやる

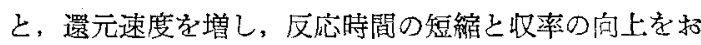
さめることができる24)。この理由は，マダネシウム粒子 の金属粉被覆破れるためと考克ている.

鼠化マグネシウム中に溶解し, 損失上なる金属粉末は $1 \mathrm{~kg}$ の塩化マグネシウムに対し， $750^{\circ} \mathrm{C}$ で，タンタルが $0.18 \mathrm{~g}$ ，ニオブが $0.25 \mathrm{~g}$ 程度で，ほとんど無視できる. また反応後の塩化マグネシウムを分析すると, 2〜5\%の ニオブまたはタンタル成分を合有するが，これは未反应 の五塩化物の溶解と推定される. 当量よりやや過剩のマ グネシゥムを必要とする理由は,図3からるかるようK， 金属粉末で括物われた未反応のマグネシウムがボート壁 に附着し，㙋化マグネシウム層中に残るためでかる。

以上の実験結果から，クロ一ル法は，純度と収率の点 でも,工業的規模での製造に適すると筆者らは判定した。

\section{4. 水素還元法}

水素還元法は, 一番古くから行われてきた歴史的方法

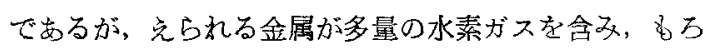
いので見捨てられていた，穴の後，真空鈰の発達に上 り，この点は除去され，庋延性にとむ金属がえられる ようになった・筆者らは，いらいろの寒験条件で，水素 還元法の収率, 純度を検討した。

（1）実験装置と操作 美験装置は、ニオブとタン

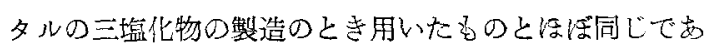
る ${ }^{153}$ 、実験操作は，三熄化物をそリブデン製ボートに入 れ，石英反応管の中央部に括き，電気炉で $600^{\circ} \mathrm{C}$ 以上 に加熱し，乾燥した水素がスを通学る。反応が終了す机 ば、アルゴン・ガスを文たして冷却する。度応の終了は， カセイカリで塩化水素を吸収させ，去の量が微少な起常 做まで減少した時をるって判定する.disproportionation のため, 生成した五垭化物は，冷却し析出させて捕集卞 ๖.

反応は，三塩化物粒子のまわりを遠元された二オブ糔 たはタンタル金属粉末が包み，クロール法のときと同し く，反度速度が低下するから，短時間だけ，10 20 $\mathrm{C}$ 温 度を上舁し，熱的刺げきを与光，この操作をくり返す ${ }^{24)}$. 金属の状態昰で，水素還元反応子進行さ也ることは，後 述の上万にかなり技術的に主らかしい，とり出した微細 な金属粉末心ェーテルで洗い乾燥する。

五塩化物を直接金属まで水素還元しようと試みても, 水素流速字大にすれば末反応の五塭化物が多く収率が雭 く, 反刘のときには低級塩化物までしか還元されず, 500 $\sim 800^{\circ} \mathrm{C}$ の還元温度筙团では成功しない。

（2）実験結果亡考察 実験結果表 3 亿示す、こ の結果から水素の流速が大きく，温度の低、性ど収率の よいことがわかる、乙加し，水素還元反応悢，高温注ど (1)，(2) 式の平衡が右辺へ傾き融 3 とは逆になる.
表 3 水素還元法による二ネブおよびタンタル 金属の製造

\begin{tabular}{|c|c|c|c|c|c|c|c|c|c|c|}
\hline 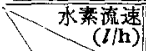 & 3 & & 6 & & 9 & 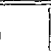 & 1 & 2 & 15 & 5 \\
\hline $\begin{array}{l}\text { 還元 } \\
\text { 温荽 }\left({ }^{\circ} \mathrm{C}\right)\end{array}$ & $\mathrm{Ta}$ & $\mathrm{Nb}$ & $\mathrm{Ta}$ & $\mathrm{Nb}$ & $\mathrm{Ta}$ & $\mathrm{Nb}$ & $\mathrm{Ta}$ & $\mathrm{Nb}$ & $\mathrm{Ta}$ & $\mathrm{Nb}$ \\
\hline 600 & 65.0 & 60.0 & 76.0 & 72.5 & 80.5 & 79.5 & 82.0 & 85.0 & 82.5 & 86.0 \\
\hline 700 & 60.5 & 55.5 & 70.5 & 67.0 & 76.0 & 75.0 & 78.0 & 81.0 & 79.0 & 83.0 \\
\hline 800 & 56.5 & 51.0 & 64.5 & 62.0 & 70.5 & 71.0 & 73.5 & 76.0 & 75.0 & 77.5 \\
\hline 900 & 54.0 & 48.0 & 60.0 & 60.0 & 66.0 & 68.0 & 70.0 & 74.5 & 72.5 & 76.0 \\
\hline 1000 & 49.0 & 44.0 & 55.5 & 54.0 & 62.0 & 65.5 & 65.5 & 70.0 & 69.0 & 74.5 \\
\hline 1100 & 46.0 & 42.0 & 52.0 & 50.5 & 57.0 & 62.0 & 62.0 & 65.0 & 66.0 & 70.0 \\
\hline 1200 & 43.5 & 40.0 & 49.0 & 47.5 & 54.5 & 59.0 & 59.0 & 62.0 & 63.5 & 67.0 \\
\hline
\end{tabular}

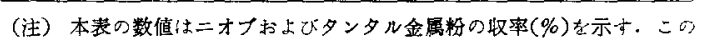
收率は，分析が困蜼なため，見かけの収革であり，特仁低い薑元温 度では，隹級塩化物か会属粉中に湿入していると考えられる。

$\cdot \mathrm{CaCl}_{3}+\frac{3}{2} \mathrm{H}_{2} \rightleftarrows \mathrm{Ta}+3 \mathrm{HCl}$

$\mathrm{NbCl}_{3}+\frac{3}{2} \mathrm{H}_{2} \rightleftarrows \mathrm{Nb}+3 \mathrm{HCl}$

この反応を考察すると、つぎの二点が問題となる。

(i) 高温では逆反成速度もかなり大きいから，生成 した湴化水素を急速俆くため，水素流速を大にする必 要がある.

(ii）高温では，一度生成したニオブまたはタンタル 金属粉が三塩化物と反店したり，いるいらの disproportionation を括こし ${ }^{16)}$ 取率を低下与る。

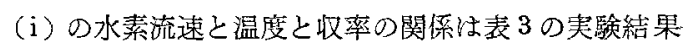
とよく一致している。（ii）が水素還元法の収率に扔上ほ す影響の主原因でむり，三塩化物の disproportionation としては主として

$$
\begin{aligned}
& 3 \mathrm{NbCl}_{3} \rightleftarrows 2 \mathrm{NbCl}_{2}+\mathrm{NbCl}_{5} \\
& 5 \mathrm{NbCl}_{3} \rightleftarrows 2 \mathrm{Nb}+3 \mathrm{NbCl}_{5}
\end{aligned}
$$

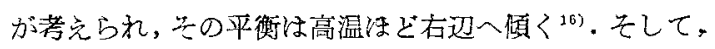
低沸点の五塩化物は気化し, 冷却部に析出し,ニオブと夕 ンタル金属の收率を低下する。 disproportionation $の る$ こりにくい低温度で還元すると，三塩化物き二塩化物々： どの低級塩化物が混入乙, 純度の高い金属粉末は兄られ

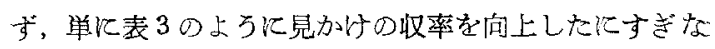

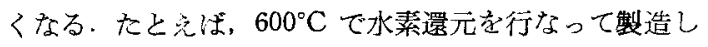
た黒色粉末に，六規定の硝酸在加竞，者沸後，硝酸銀で 口 液を滴定すると，かなり多量の㙁素分が残存している。

以上の観点から，ニオブとタンタル金属の製造では， 還元温度 $700 \sim 800^{\circ} \mathrm{C}$, 水素流速は $12 \sim 15 l / \mathrm{h}$ 以上, 迫元 部の水素滞在時間 $0.6 \sim 0.8 \mathrm{~min}$ 程度が適当と考方られ る、還元金属粒末の粒度は，他の二方法のように，90\% 以上が 250 メッシュより微細である。

\section{5. 諸還元法の比汃く}

(1) 諸遇元法の比かく Mc Intosh 5 対する Discussion で Powell ら ${ }^{17)}$ によて諸還元法の圠

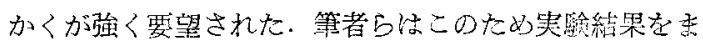


表 4 諸還元法の比放く

\begin{tabular}{|c|c|c|c|c|c|}
\hline 遠 元 法 & 験＼cjkstart条 & 英 & 験 & 果 & 害 \\
\hline ツェペリン法 & 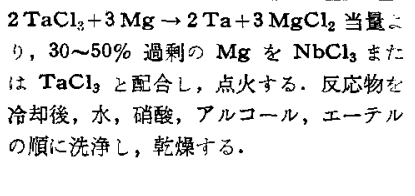 & 金属 & $\begin{array}{l}\text { 純 } \\
<99.2 \\
\ll 99.0\end{array}$ & $\begin{array}{l}\text { 収 } \\
\qquad 68 \sim 70 \\
\leqslant 70\end{array}$ & 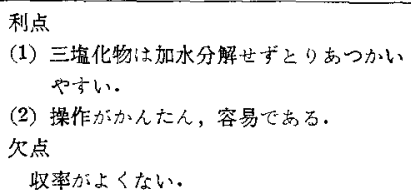 \\
\hline クロール法 & 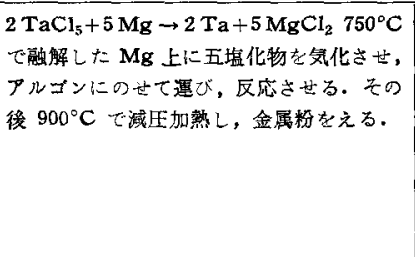 & 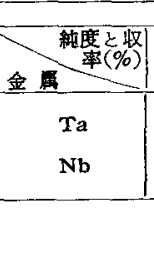 & $\begin{array}{l}\text { 純 } \\
<99.6 \sim 99.8 \\
<99.5\end{array}$ & $\begin{array}{c}<72 \sim 77.5 \\
<75\end{array}$ & 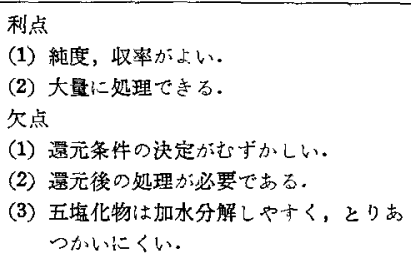 \\
\hline 水素僄元法 & 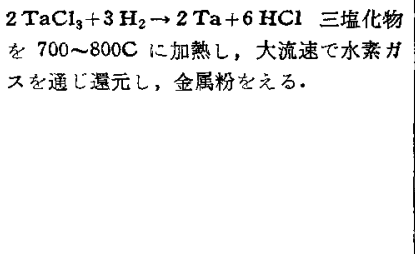 & $\frac{\mathrm{T}_{\mathrm{Ta}}}{\mathrm{T}}$ & $\begin{array}{l}\text { 䋘 } \quad \text { 度 } \\
<99.4 \\
<99.2\end{array}$ & $\begin{array}{l}\text { 収 } \quad \text { 率 } \\
<76.0 \sim 79.0 \\
<77.5 \sim 83.0\end{array}$ & 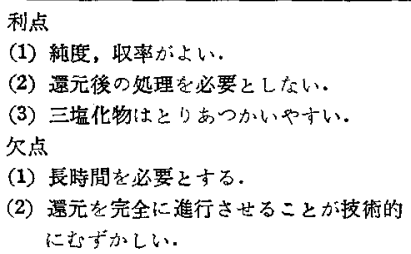 \\
\hline
\end{tabular}

表 5 還元法によりえられるニオブ金属の純度（\%)

\begin{tabular}{|c|c|c|c|}
\hline 2 & 金属 & 粉 & \\
\hline 不維物 & $\begin{array}{l}\text { フッ化物の } \\
\mathrm{Na} \text { 賞 }\end{array}$ & 塩化物の水素僄元 & 330 物 \\
\hline $\mathbf{H}_{2}$ & $0.20 \sim 0.30$ & $0.8 \sim 1.0$ & $0.0001 \sim 0.001$ \\
\hline $\mathrm{O}_{2}$ & $0.30 \sim 0.50$ & $0.01 \sim 0.03$ & $0.005 \sim 0.05$ \\
\hline $\mathbf{N}_{2}$ & $0.03 \sim 0.07$ & $0.07 \sim 0.15$ & $0.002 \sim 0.01$ \\
\hline C & $0.20 \sim 0.30$ & $0.02 \sim 0.05$ & $0.001 \sim 0.01$ \\
\hline $\mathrm{Ta}$ & $0.10 \sim 0.30$ & $0.10 \sim 0.20$ & $0.10 \sim 0.20$ \\
\hline Si & $0.03 \sim 0.08$ & $0.03 \sim 0.08$ & $0.007 \sim 0.01$ \\
\hline $\mathbf{F e}$ & $0.02 \sim 0.05$ & $0.05 \sim 0.20$ & $0.02 \sim 0.05$ \\
\hline $\mathrm{Ti}$ & $0.03 \sim 0.06$ & $0.03 \sim 0.06$ & $0.03 \sim 0.06$ \\
\hline Sn & $0.03 \sim 0.08$ & $0.03 \sim 0.08$ & $0.03 \sim 0.08$ \\
\hline $\mathbf{P b}$ & $0.05 \sim 0.10$ & $<0.03$ & $<0.005$ \\
\hline $\mathbf{M g}$ & $<0.10 \sim 0.30$ & $<0.07 \sim 0.20$ & $<0.001$ \\
\hline $\mathrm{Al}$ & $<0.03$ & $<0.03$ & $<0.01$ \\
\hline $\mathrm{Mn}$ & $0.05 \sim 0.10$ & $0.01 \sim 0.30$ & $0.01 \sim 0.30$ \\
\hline $\mathrm{Ni}$ & $<0.01$ & $<0.03$ & $<0.01 \sim 0.03$ \\
\hline $\mathrm{Be}$ & 0.01 & $0.03 \sim 0.10$ & $0.01 \sim 0.10$ \\
\hline $\mathrm{Cr}$ & $<0.03$ & $<0.03 \sim 0.10$ & $<0.03 \sim 0.10$ \\
\hline Co & $<0.01$ & $<0.03$ & $<0.01 \sim 0.03$ \\
\hline Mo & $0.01 \sim 0.03$ & $0.03 \sim 0.05$ & $0.01 \sim 0.05$ \\
\hline $\mathbf{B i}$ & $<0.03$ & $<0.05 \sim 0.15$ & $<0.01 \sim 0.03$ \\
\hline Sb & $<0.05$ & $<0.05$ & $<0.05$ \\
\hline $\mathrm{v}$ & $<0.03$ & $<0.03$ & $<0.03$ \\
\hline $\mathbf{w}$ & $<0.10$ & $<0.30$ & $<0.10 \sim 0.30$ \\
\hline$Z_{n}$ & $<0.10$ & $<0.30$ & $<0.01$ \\
\hline $\mathrm{Nb}$ & $>97.33 \sim 98.45$ & $>96.45 \sim 97.82$ & $>98.48 \sim 99.51$ \\
\hline
\end{tabular}

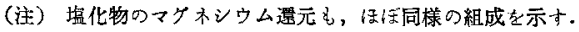

とめ，二オブとタンタルの塩化物から工業的規模で応用 できる金属粉末の製造方法として，純度と収率を考充に 入れ，表 4 を作成した．その結論はつぎのと括りである。

(i ）クロール法と水素還元法の優劣は，ほとんどな w. （ii）しかし，クロール法は，水素還元法上り純度の 点でややまさり，收率の点ではやや劣る。

(iii) 上の二方法とくらベ,ツェペリン法は収率, 純 度と事炕劣る。

\section{（2）遇元法でえられるニオブとタンタルの純度}

還元法でえられるニオブ金属の純度は，原子炉材とし て使用するとき，重要な問題となる。るらるん，純度は， 原料鎕石，製造法，装置材料，製造技術，收率の目標など が関係し簡単ではない，筆者らは自分の丰験をるとに， 諸文献を参照し4)6718)19720)ニオブ金属の純度をまとめ, 表 5 に示した。电し，原鉱石としてタンタライトを用いれ ば,コバルト，クロム，ニッケル，アンチモン,ソウ鉛， バナジウムなどの混入はないから，西鈆，スズなどの成 分を注意して除去すれば, 容易に $99.7 \%$ まで達する.

タンタル金属については, 電解コンデンサなとの用途上 の関係加ら，ニオブほどの高純度は問題としないことが 多いが，同様に考光てよい，混入するガスは，焼結加工 で表5のようにかなり除去できるので，ぼの方法によっ て子注意しさえすれば，展延性のある金属がえられる。

\section{6. 新乾式製錬法}

筆者らの行なった鉱石の塩素化による新乾式製錬法を まとめると図4のようになる。この図で，筆者らの独自 の工程はつぎの諸点である。

(i) 鈗石圶直接塩素化したこと.

(ii) ニオブの精製分離に，分留と選択的水素還元を 併用したこと.

（iii）タンタルの精製分離に分留と disproportiona- 


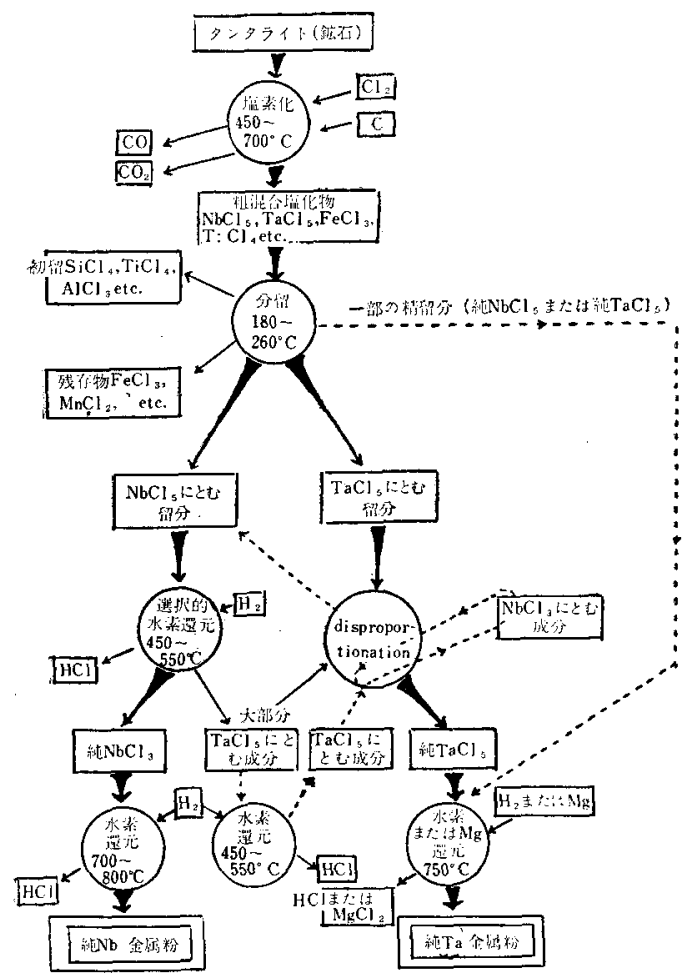

図 4 簐者らの塩素化法工程図

tion 利用したこと.

(iv) 不純なニオブとタンタルを塩化物のまま，分別 的に分離回收したこと.

（v）融解塩電解法によらず，マグネシウム（または 我素）還元法によって金属粉末をえたこと.

こうして筆者らの研究の結果，今まで困難とされてい た純ニオブとタンタル金属を，簡単な工程で，大量に短 特間で収率よく製造できる方法を明らかにすることがで きた。

$$
\text { 7.ま亡 め }
$$

（1）塩化物を，マグネシウム，カルシウム，水素で
還元して，ニオブとタンタル金属の粉末を製造した。

(2) その結果，つぎの諸点を明らかにした.

(i) クロ一ル法と水素還元法の優少はほとんどな W.

(ii）乙かし，クロール法は，水素還元法より，収率 はやや少るが，純度はよい。

(iii）ツェペリン法は上の二方法より, 純度, 収率が とも劣っている。

（3）以上の諸方法によって製造した金属粉末の収率 㤌 72〜83\%, 純は 99.2 99.5\% 前後であった.

(4) 筆者らのニオブとタンタルの乾式製鏮法をまと め,その独自の点を明らかにした。（昭 33-12-17 受理）

\section{文 献}

1) F.H. Drigos, W.C. Lilliendal, Ing. Eng. Chem. 23, 634 (1931).

2) C.W. Balke, Trans. Electrochem. Soc. 85, 89 (1944).

3) G.K. Dickson, J.A. Dukes, Extraction and Refining of the Rarer Metals, (1957), p. 253

4) H.A. Johansen, S.L. May, Ind. Eng. Chem. 46, 2499 (1954).

5) J.P. Isaza, A.J. Schaler, J. Wulff, Am. Inst. Min. Met. Engs. Met. Technol. 14, No. 6, Tech. Pub. No. 2277(1947).

6) A.B. Mclntosh, J.S. Broadley, 前出 3), p. 272.

7) H. Schäfer, U.S. Pat. 2,766,112 (1956).

8) H. Zeppelin, Metal. u. Erz. 40, 252 (1943).

9) J. Hooper. A.E. Williams : 能出 3), p.- 143

10) E. Folly, M. Ward, A.L. Hock, 前出 3), p. 196.

11) A.B. Mc Intosh, Ibid. p. 305.

12) C. Tyzack, P.G. England, Ibid. p. 175. バナジウムのげかい 学参照.

13) H.C. Rentschler, W.C. Lilliendal, U.S. Pat. 2,446,062 (1948). 2,537,067 (1951).

14) J.W. Marden, H.C. Rentschler, Ind. Eng. Chem. 19, 97 (1927).

15) 石山豊次，黑田 正，第 3 埌

16) Sibert 5们熱力学的概算值加報告されている. B.W. Gonser, E.M. Sherwood, Technology of Columbium (Niobium) (1958), p. 20

17) A.R. Powell, 前出 3), p. 300 .

18) M.D. Jepson, Research. 10, 390 (1957).

19) L.R. Williams, J. Inst. Metals. 85, 385 (1957).

20) W.G. O'Driscol, Ibid. 85, 379 (1957).

21) 測定法法 Dr. Temple, 前出 3), p. 348

22) C.J. Smithells, Met. Ind. London, 38, 336 (1931).

23) J. Glasser, C.A. Hampel, U.S. Pat. 2,703,752 (1955).

24) 前出 3)の p. 278 参照.

\section{$\mathrm{CaC}_{2}=\mathrm{Ca}+2 \mathrm{C}$ 反応の平衡 $\mathrm{Ca}$ 蒸気圧の測定}

\section{Measurements of the Equilibrium $\mathrm{Ca}$ Vapor Pressure \\ on the Reaction $\mathrm{CaC}_{2}=\mathrm{Ca}+2 \mathrm{C}$}

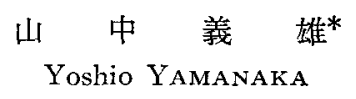

\section{1. 緒言}

カルシウム・カーバイドを高温に熱すると、つぎのよ

*信越化学工業株式会社 直江津工場（新潟県直江津市）
うに分解する.

$$
\mathrm{CaC}_{2}=\mathrm{Ca}+2 \mathrm{C}
$$

委た，カルシウム・カーバイドは，次の 2 段階の反応 をへて生成する，と考克るのが今日の定説となっている. 